\title{
Evaluating the Perspectives of the Administrators Attended to Quality Management Education Enhanced By Teamwork Activities
}

\author{
Yöneticilerin Takım Çalışması Etkinlikleri İle \\ Desteklenmiş Kalite Yönetimi Eğitimine Katılıma Bakış \\ Açılarının Değerlendirilmesi
}

\author{
Yetkin Utku Kamuk ${ }^{\mathbf{1}}$ (iD https://orcid.org/0000-0001-5976-7503 \\ Faculty of Sport Sciences, Hitit University, Çorum, Turkey
}

\section{Zafer Doğru \\ (iD) https://orcid.org/0000-0002-8902-0301}

Faculty of Sport Sciences, Hitit University, Çorum, Turkey

Received: 02.09.2019

Accepted: 28.09.2019

Online Published: 30.09.2019

DOI: 10.30655/besad.2019.20

https://doi.org/ 10.30655/besad.2019.20

\begin{abstract}
The aim of this study was to examine the thoughts of the organizational managers who participated in quality management training which was enhanced by group dynamics activities. For this purpose, group dynamics activities were carried out during the training of 60 administrators, including academic and administrative personnel, who had attended the 2-day Hitit University Quality Management Training. The participants were asked to take part in three twenty-minute sessions of group dynamics events. Following the Quality Management Training, a web-based survey was conducted to obtain data from the participants by using the evaluation form designed by the researchers. It was concluded that participation in the group dynamics activities contributed to increase the efficiency of the training, increased the motivation for the training participation, and affected the sense of belonging at work positively.
\end{abstract}

Keywords: Group dynamics, problem solving, physical activity.

${ }^{1}$ Corresponding author: Yetkin Utku Kamuk Hitit Üniversitesi, Spor Bilimleri Fakültesi, Kuzey Kampüsü Çevre Yolu Bulvarı 19030 Çorum, Turkey yetkinkamuk@hitit.edu.tr 


\section{Öz}

Bu çalışmanın amacı, kurum içi eğitim toplantısı olarak düzenlenen Kalite Yönetimi Eğitimi'ne katılım sağlayan üniversite yöneticileri için tasarlanmış olan takım çalışması etkinliklerine iştirak eden yöneticilerin bu aktivitelere katııma ilişkin görüşlerinin incelenmesidir. Araştırma kapsamında, 2 gün süre ile devam etmiş olan Hitit Üniversitesi Kalite Yönetimi Eğitimi'ne katılan, akademik ve idari personelin yer aldığı 60 yöneticiye eğitim süresince takım çalışması etkinlikleri uygulamaları yaptıılmıştır. Katıımcılara, eğitim seanslarının aralarında olacak şekilde dört kez 20'şer dakikalık etkinlikler planlanmıştır. Etkinliklere katıımın etkilerinin değerlendirilmesi amacıyla, araştırmacılar tarafından tasarlanan değerlendirme formu kullanılarak web tabanlı veri toplama yöntemi ile elde edilen bilgilere göre, takım çalışması etkinliklerine katıımın, yöneticilerin eğitimin veriminin artmasına katkı sağladığı, eğitime katııma ilişkin motivasyonlarını yükselttiği, kurumsal aidiyet duygularını olumlu etkilediği sonucuna ulaşılmışsır.

Anahtar kelimeler: Grup dinamiği, problem çözme, fiziksel aktivite.

\section{Giriş}

Organizasyonların başarılı olabilmesi için, organizasyonu oluşturan parçaların uyum içerisinde hareket etmesi gerektiği bilinmektedir. Bununla birlikte, profesyonel yaşamı meydana getiren tüm unsurlardaki (insan, malzeme, teknoloji vb.) değişim ve gelişime ayak uydurmak ve meydana gelen değişimlere süratli şekilde adapte olabilmek için çalışma hayatının kalite düzeyinin iyi düzeyde olmasına ihtiyaç duyulmaktadır (Aktan, 2016). Profesyonel iş hayatında, uzmanlık alanlarına ait bilgilere ek olarak, kendi duygusal yapısını iyi tanıyan ve kapasitesinin sınırlarının farkına varmış, inovasyona açık, kendisinin ve kurumunun hedeflerine ulaşmaya istekli çalışanlara gereksinim vardır. Bununla birlikte, takım çalışmasına adapte olabilen, iletişim becerisi yüksek ve problem çözme yeteneği olan çalışanların kuruma katkısı da yadsınamaz (Selimoğlu \& Yılmaz, 2009).

Kurum personeline verilen eğitimin personel için anlamı geçmişte sadece teknik bilgilerin verilmesi iken, günümüzde gelinen noktada kurum içi eğitimler, karar alma ve uygulayabilme, hızlı ve ani gelişen değişimlere ayak uydurabilme, baskı altında görevi yerine getirebilme ve her koşulda görevi sürdürebilme yetileri kazandırmayı amaçlamaktadırlar (Görmüş \& Kahya, 2014). Kurumların, zaman içerisinde değişen bu duruma ayak uydurabilmeleri zaruri hale gelmiştir. Değişime adaptasyon için, yöneticiler başta olmak üzere tüm paydaşların yaratıcııklarından ve yeteneklerinden faydalanılması gerekmektedir. Günümüzde kurum yöneticileri, diğer kurumlarla rekabet güçlerini koruyabilmek maksadıyla çalışanlarının yeteneklerini desteklemek üzere girişimlerde bulunmaktadırlar (ilhan \& ince, 2015). Kurumlar için, personelin işbirliği içerisinde çalışmasının önemi hem takım üyelerinin uyumu hem de ekonomik açıdan önemlidir. İşbirliği içerisinde çalışmak, çok değerli olan zamandan tasarruf etmeye ve zamanın etkin kullanılması sayesinde vakit kayıplarının önüne geçilmesine olanak sağlar. Çalışma yaşamında değeri ölçülemeyecek kadar yüksek olan zamanın iyi bir şekilde kullanılabilmesi, başarının elde edilmesinde kilit role sahip olan unsurdur (Gürbüz \& Aydın, 2012) ve takımın her bir üyesinin karar ve çözüme katkısı sağlandığında takım çalışması başarılı olmaktadır (Güçlü \& Okçu, 2015).

Bireyler arası iletişimin kurulabilmesi ve güçlendirilebilmesi için kullanılabilecek olan pek çok yöntem olmakla birlikte, her türlü fiziksel aktiviteye, ya da fiziksel aktivitelere dayalı takım çalışmalarına, katıım oldukça etkili bir yöntemdir. Fiziksel aktivitelere katılım bireylerde, diğer insanlarla iletişim kurabilmeyi, olaylar karşısında pozitif düşünebilmeyi ve zor koşullarda stres faktörüyle mücadele gücünü geliştirmeyi sağlamakta yardımcı olur. Fiziksel aktivitelere katıım yoluyla bireylerin toplum tarafından kabullenilmeleri ve sosyal gruplara dâhil olabilmeleri daha kolay hale gelmektedir (Bek, 2008). Grup içerisinde yapılan tüm fiziksel etkinlikler toplumsal bir olgudur ve bireylerin duygularını etkilemektedir. Fiziksel etkinlikler sırasında bireyler kendilerini daha rahat ifade edebilme, duygularını bir kalıp 
içerisinde olmaksızın aktarabilme şansı bulurlar. Bu da bireylerde psikolojik olarak rahatlamaya ve stresten uzaklaşmaya neden olmaktadır (Yetim, 2000).

Yukarıda verilen bilgiler ışığında, bu çalışmanın amacı, iki gün süren kalite yönetimi eğitimine iştirak eden kurum yöneticileri için planlanmış olan, fiziksel aktiviteye dayalı olarak tasarlanmış takım çalışması etkinliklerine katıımın etkilerinin değerlendirilmesidir.

\section{Yöntem}

Araştırmanın evrenini Hitit Üniversitesi bünyesinde görev yapan Fakülte Dekanları, Yüksekokul ve Enstitü Müdürleri, Daire Başkanları, Rektörlüğe doğrudan bağlı birimlerin yöneticileri ve kalite komisyonu üyeleri ( $\mathrm{N}=60$ ); örneklemini ise, evren içerisinde yer alan ve yapılan online davete olumlu cevap vererek araştırmaya gönüllü olarak katıım sağlayanlar $(n=42)$ oluşturmaktadır.

Çalışmanın gerçekleştirilebilmesi için Hitit Üniversitesi Rektörlüğü'nden kurum izni alınmıştır. Düzenlenmiş olan kalite yönetimi eğitimi süresince yapılan takım çalışması etkinliklerine katılan bireylerden, kişisel bilgiler ve etkinliklere ilişkin görüşler olmak üzere iki bölümden oluşan ankete katıım sağlamaları istenmiştir. Online olarak hazırlanmış olan veri toplama aracı, katılımcıların elektronik posta adreslerine, etkinliklere katıımı takip eden 24 saat içerisinde gönderilmiş, araştırmaya gönüllü katılmayı kabul eden katıımcıların görüşleri, gönüllü katılımlarını dijital olarak beyan etmelerinin ardından, anonim olarak toplanmıştır. Beşli Likert tipi ölçek kullanılarak oluşturulan formda, Katılımcıların verilmiş olan ifadeler için, kendilerine en uygun olan cevabı işaretlemeleri istenmiştir. Elde edilen verilerin gerçek değerlendirme aralıklarının "1,00-1,80" hiç katılmıyorum, "1,81-2,60" katımıyorum, "2,61-3,40" kararsızım, "3,41-4,20" katılıyorum, "4,21-5,00" tamamen katılıyorum şeklinde olduğu hesaplanmıştır.

Tanışma etkinliği toplantının birinci seansının bitiminde, diğer etkinlikler ise, her iki oturum arasında olacak şekilde, dört farklı uygulama seansı şeklinde gerçekleştirilmişsir. Katılımcılara, oturumlar arasında etkinliklerin düzenleneceği önceden bildirilmiş ve etkinlikler, oturumların yapıldığı konferans salonuna komşu olan diğer konferans salonunda, gerekli fiziksel düzenlemeler yapılması sonrasında gerçekleştirilmiştir. Katıımcılardan, etkinliklere katııma istekli olanlar ve etkinliğe katılmaya mani herhangi bir sağlık sorunu olmadığını beyan edenler iştirak etmiştir. Her seans yaklaşık 20 dakika sürmüştür. Seanslar içerisinde yer alan uygulamalara ilişkin açıklamalar aşağıda verilmiştir.

'Top'lu Tanışma: Bir çember şeklinde yan yana dizilen katılımcılardan, isimlerini sırayla ve yüksek sesle söylemeleri istenmiştir. Saat yönünde herkesin kendi ismini söylemesinin ardından, her katılımcıdan, kendisinden sonra gelen kişinin ismini hatırlaması ve doğru olarak söylemesi istenmiştir. Uygulatıcının komutuyla birlikte, isim söyleme işleminin yön değiştirmesi istenmiş ve herhangi bir zamanda olmak üzere bir kaç kez yön değişimi sağlanmıştır. Ardından katıımcılara farklı renkte (mavi ve kırmızı) iki sünger top verilerek topları saat yönünde elden ele aktarmaları ve bu esnada, topu ilettikleri kişinin adını söylemeleri istenmiştir. Mavi olan top katıımcının yanında duran katıımcıya, kırmızı top ise katıımcının yanındaki kişiden sonraki katıımcıya verilecek şekilde iletilmiştir. Bu etkinliğin süresi yaklaşık 15 dakikadır.

Pipet ile Top Yürütme: Katılımcılar, yerden $100 \mathrm{~cm}$ yükseklikte, $8 \mathrm{~m}$ uzunluğunda ve $60 \mathrm{~cm}$ genişliğindeki bir parkurda yerleştirilmiş olan engeller arasından masa tenisi toplarını hareket ettirerek, hedefe ulaştırmaya çalışmışlardır. Katıımcıların topları hareket ettirebilmek için pipetlerden üflemeleri gerekmektedir. Toplara herhangi bir fiziksel temasa izin verilmemiştir. Parkuru oluşturan 2 m'lik parçaların her biri hafif eğimli olarak yerleştirilmiş, topu ilerletecek olan etki azaldığında, topun başlangıç noktasına doğru geri hareket etmesi sağlanmıştır. Bu etkinliğin süresi yaklaşık 15 dakikadır. 
Sihirli Değnek: Katılımcılardan; yüzleri birbirine bakacak, her iki el işaret parmakları karşıdaki kişiyi işaret eder ve birbirlerine yaklaşık bir kol boyu mesafede olarak şekilde pozisyon almaları istenmiştir. İşaret parmaklarının üzerine yerleştirilen yaklaşık 4 m'lik hafif metal çubuğun parmaklarının üzerine teması kesilmeksizin yere indirmeleri istenmiştir. Bu etkinliğin süresi yaklaşık 15 dakikadır.

Yön Değiştirme: Katılımcılar 15'er kişilik gruplara ayrılmış ve yüzleri merkeze dönük olacak şekilde bir çember oluşturmaları istenmiştir. Katılımcıların tümü her iki yanında yer alan kişilerle el ele tutuşarak etkinlik için başlangıç pozisyonu alınmıştır. Katıımcılardan, ellerini bırakmadan, tüm katılımcıların sırtı merkeze dönük olacak şekilde yeni bir çember oluşturmaları istenmiştir. Bu uygulamanın süresi yaklaşık 5 dakikadır.

Büyük Çember Oluşturma: Katılımcılar 15'er kişilik gruplara ayrılmış, yüzleri merkeze dönük olacak şekilde bir çember oluşturmaları istenmiştir. Her katıımcı yanındaki katılımcıdan sonraki katılımcının elini tutarak, birbirine geçmiş iki halka oluşturmuştur. Katılımcılardan istenen, ellerini bırakmadan büyük bir çember oluşturmaktır. Bu uygulamanın süresi yaklaşık 5 dakikadır.

Koordinasyon Evi: Üzerine sabitlenmiş bir kaleme sahip olan plakaya bağlanmış 15 adet ipin her birinin ucundan tutularak, masa üzerine yapıştırılmış olan büyük boy fon kartonuna, yalnızca iplerin ucundan tutmak suretiyle, 15 kişinin katkılarıyla basit bir ev resmi (kare ve üzerinde yer alan üçgen) çizilmesi istenmiştir. Bu uygulamanın süresi yaklaşık 5 dakikadır.

Top Taşıma: Katılımcılardan, yuvarlak bir plakaya bağlı 15 ipin her birinin ucundan tutularak, plakanın yukarı doğru hareket ettirilmesi ve plakanın içinde bulunan boruyu düşürmeden, borunun üzerinde yer alan topu plaka üzerinde tutmaları ve düşürmeden taşıyarak, diğer borunun üzerine topu yerleştirmeleri istenmiştir. Hareket esnasında borular ya da topun yere düşmemesi gereklidir. Bu uygulamanın süresi yaklaşık 10 dakikadır.

Kanalda Top Taşıma: Katılımcılar 20'şer kişilik gruplara ayrılarak her bir gruba 30'ar cm uzunluğunda 3'er adet kanal verilmiştir. Katıımcıların amacı, kanal içerisine yerleştirilen topu düşürmeden, hemen yanında yer alan katıımcının elindeki kanala topu aktarmak ve kendi elindeki kanalı, topun ilerlemesi için bu kanala intiyacı olacak olan ilk katılımcıya verip sıranın sonuna hızlı bir şekilde koşarak geçmek ve böylelikle topu düşürmeden hedefe ulaştırmaktır. Bu uygulamanın süresi yaklaşık 5 dakikadır.

Ayrılamam Senden: Katılımcılar özel olarak hazırlanmış $80 \mathrm{~cm}$ uzunluğundaki ipleri el bileklerinden geçirerek bağlamışlardır. Daha sonra iki katılımcının birbirine bağlanması için, bir katılımcının sağ el bileğindeki ip çıkartılarak, eşinin ipi ile gövdesi arasındaki boşluktan geçirilerek, tekrar kendi bileğine bağlanmıştır. Bu şekliyle, iç içe geçmiş zincir halkalarına benzeyen pozisyondan, bileklerindeki ipleri çözmeden ve ipleri koparmadan birbirlerinden ayrılmaları istenmiştir. Bu uygulamanın süresi yaklaşık 5 dakikadır.

Verilerin istatistiksel analizi SPSS (IBM Corp. 2013, Release 22.0.0.0, 64-bit edition; Lisans: Hitit Üniversitesi) paket programı kullanılarak gerçekleştirilmiştir. Elde edilen verilerin çözümlenmesi için tanımlayıcı istatistikler, yüzde ve frekans tabloları kullanılmıştır. İstatistiksel incelemeye tabi tutulacak olan alt grup sayılarının küçük ( $n<30$ ) olması nedeniyle, istatistiksel analizlerin gerçekleştirilebilmesi için parametrik olmayan testlerden faydalanımıştır. Çoklu gruplar arasındaki farklııkların belirlenmesi amacıyla Kruskal-Wallis (KW) ve ikili grup karşılaştırmalarında Mann-Whitney $U$ (MWU) testi kullanılmıştır. İkili grup karşılaştırmalar için kullanılan istatistiksel analizlerde anlamlılık düzeyi p<0,05 olarak belirlenmişstir. Çoklu gruplar arasında fark olduğunun KW testi ile belirlenmesinden sonra, hangi 
gruplar arasında farkın var olduğunu incelemek için MWU testi kullanılmış ancak Bonferroni düzeltmesi uygulanarak anlamlılık düzeyi yeniden hesaplanmıştır.

\section{Bulgular}

Araştırmaya, 42 katılımcı (31 erkek, 11 kadın) iştirak etmiştir. Yaş ortalamalarına bakıldığında, erkek akademik personelin $(n=16)$ yaş ortalamasının 43,94 $( \pm 6,66)$ yıl, kadınların $(n=6)$ ise $44,17( \pm 6,85)$ yıl olduğu görülmektedir.

İdari personelin yaş ortalamalarına bakıldığında, erkek personelin ( $\mathrm{n}=15)$ kadın personelden $(\mathrm{n}=5)$ daha

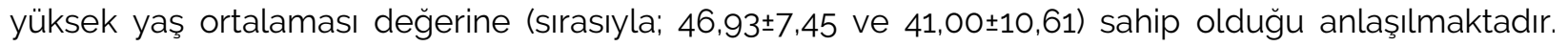
Katıımcıların kurumda çalışma süreleri ise ortalama 8,45 yıl $( \pm 5,24)$ 'dır. Toplam hizmet süreleri incelendiğinde, katılımcıların genel ortalamasının 20 yılın üzerinde $(20,74 \pm 8,26)$ olduğu görülmektedir. Katılımcıların 22'si akademik personel iken, 20'si idari personelden oluşmuştur. (Tablo 1).

Tablo 1. Katıımcılara İlişkin Tanımlayıcı İstatistikler

\begin{tabular}{|c|c|c|c|c|c|c|c|c|}
\hline \multirow{2}{*}{\multicolumn{2}{|c|}{ Kategori }} & \multirow{3}{*}{$\begin{array}{c}n \\
16\end{array}$} & \multicolumn{2}{|c|}{ Yaş } & \multicolumn{2}{|c|}{ Kurumda Çalışma Süresi } & \multicolumn{2}{|c|}{ Toplam Hizmet Yılı } \\
\hline & & & Xort & $S D$ & Xort & $S D$ & Xort & $S D$ \\
\hline \multirow{2}{*}{$\begin{array}{l}\text { Akademik } \\
\text { Personel }\end{array}$} & Erkek & & 43,94 & 6,66 & 7,75 & 5,23 & 19,06 & 6,34 \\
\hline & Kadın & 6 & 44,17 & 6,85 & 7,00 & 6,54 & 21,17 & 5,64 \\
\hline \multirow{2}{*}{$\begin{array}{l}\text { Idari } \\
\text { Personel }\end{array}$} & Erkek & 15 & 46,93 & 7,45 & 9,00 & 4,21 & 23,47 & 9,38 \\
\hline & Kadın & 5 & 41,00 & 10,61 & 10,80 & 7,09 & 17,40 & 12,12 \\
\hline \multicolumn{2}{|c|}{ Toplam } & 42 & 44,69 & 7,46 & 8,45 & 5,24 & 20,74 & 8,26 \\
\hline
\end{tabular}

Katılımcıların takım çalışması etkinliklerine katılım hakkındaki görüşleri incelendiğinde, etkinliklerin sayısal olarak yeterli miktarda olduğunu belirten katılımcı sayısı 27 (\%64,29) iken, diğer Katılımcıların etkinlik sayısını az (n=14; \%33.33) ya da çok az (n=1; \%2,38) olarak ifade ettikleri görülmüştür (Tablo 2). Araştırmaya katılan Katıımcıların yarısından fazlası $(n=22 ; \% 52,38)$ takım çalışması etkinliklerine daha önce de katıldığını beyan etmişstir. Etkinliklerin süresi incelendiğinde, Katıımcıların çoğunluğunun ( $n=29$; \%69,05) etkinliklerin süresini tam kararında olarak ifade ettiği, 12 katılımcının $(\% 28,57)$ etkinliklerin süresini kısa ve çok kısa olarak değerlendirdikleri, sadece bir katılımcının etkinliklerin süresini gereğinden uzun olarak değerlendirdiği $(\% 2,38)$ görülmektedir.

Genel olarak etkinliklerin faydasının değerlendirilmesi istendiğinde, katılımcılar etkinlikleri faydalı ( $\mathrm{n}=15$; \%35,71) ve çok faydalı $(n=27 ; \% 64,29)$ bulduklarını belirtmişlerdir. Etkinliklerin faydalı olmadığını belirten katıımcı bulunmamaktadır.

Amaca uygunluk durumu açısından bakıldığında ise, etkinliklerin iyi tasarlanmış ve amaç ile tam olarak örtüştüğünü belirten katılımcı sayısı 30 (\%71,43), amaca hizmet eden faydalı aktiviteler olduğunu belirten katıımcı sayısı ise 11 (\%26,19)'dir. Etkinliklerin amaca uygunluk açısından değerlendirilmesi sonucunda, etkinliklerin bir amaca hizmet etmediğini düşünen bir katılımcı $(\% 2,38)$ haricindeki katılımcıların ( $n=41 ; \% 97,62$ ) olumlu görüş bildirdiği görülmektedir.

Katıımcıların tamamı ( $n=42 ; \% 100)$, bu tip etkinliklerin gelecekte katılım sağlayacakları eğitim, kongre ve benzeri toplantılarda yer almasını istediklerini beyan etmişlerdir. Katılımcıların gerçekleştirilmiş olan takım çalışması etkinliklerine katılıma ilişkin görüşleri tüm maddelerde pozitif yöndedir. 
Tablo 2. Katılımcıların Etkinliklere Katılıma İlişkin Görüşleri $(n=42)$

\begin{tabular}{|c|c|c|}
\hline Daha önce, takım çalışması etkinliklerine katıldınız mı? & $f$ & $\%$ \\
\hline Katıldım & 22 & 52,38 \\
\hline Katılmadım & 20 & 47,62 \\
\hline \multicolumn{3}{|l|}{ Gerçekleştirilen etkinliklerin süresi hakkında ne düşünüyorsunuz? } \\
\hline Gereğinden uzundu & 1 & 2,38 \\
\hline Tam kararındaydı & 29 & 69,05 \\
\hline Kısaydı & 11 & 26,19 \\
\hline Çok kısaydı & 1 & 2,38 \\
\hline \multicolumn{3}{|l|}{ Gerçekleştirilen etkinliklerin sayısı hakkında ne düşünüyorsunuz? } \\
\hline Çok Azdı & 1 & 2,38 \\
\hline Azdı & 14 & 33.33 \\
\hline Tam Kararındaydı & 27 & 64,29 \\
\hline \multicolumn{3}{|l|}{ Yapılmış olan etkinlikler hakkında genel olarak ne düşünüyorsunuz? } \\
\hline Faydalı Olmadı & - & 0,00 \\
\hline Faydalı Oldu & 15 & 35,71 \\
\hline Çok Faydalı Oldu & 27 & 64,29 \\
\hline \multicolumn{3}{|l|}{ Yapılmış olan etkinliklerin amaca uygunluğu hakkında ne düşünüyorsunuz? } \\
\hline Sadece etkinlikti, herhangi bir amaca hizmet ettiğini düşünmüyorum & 1 & 2,38 \\
\hline Amaca hizmet eden, faydalı aktivitelerdi & 11 & 26,19 \\
\hline İyi tasarlanmış ve amaç ile tam olarak örtüşen aktivitelerdi & 30 & 71,43 \\
\hline \multicolumn{3}{|c|}{ Gelecekte katılacağınız eğitim, kongre vb.lerde bu tip etkinliklerin olmasını ister misiniz? } \\
\hline Evet & 42 & 100,00 \\
\hline
\end{tabular}

Katılımcıların ifadelere verdikleri cevaplar cinsiyet ve personel statüsü kategorilerine göre değerlendirildiğinde (Tablo 3); erkeklerde, "...problem çözme becerime katkı sağladı." ifadesinin puanının $(3,87 \pm 1,06)$ en düşük, "...eğitim seanslarına düzenli katıım için motivasyonumu artıırdı." ifadesinin puanının $(4,55 \pm 0,68)$ ise en yüksek puan olduğu görülmüştür. Kadınlarda ise; "...iş yaşantıma olumlu katkılar sağlayacaktır" ifadesinin puanı $(4,00 \pm 0,89)$ en düşük, "...eğitim seansları arasında enerjimi yenilememi sağladı" ifadesinin puanı $(4,91 \pm 0,30)$ ise en yüksek puandır. Cinsiyete göre değerlendirildiğinde, katılımcılar tarafından ifadelere verilen puanların ortalamaları katılıyorum ve kesinlikle katılıyorum düzeyindedir $(3,87 \leq X o r t \leq 4,91)$. Akademik ve idari personelin ifadelere verdikleri puanlar incelendiğinde (Tablo 3); akademik personelin en düşük puanı $(3,82 \pm 1,10)$ "...işlerin her zaman olmayabileceğini hissettirdi" ifadesine verdiği, en yüksek puanı $(4,73 \pm 0,55)$ ise "... başarıyla tamamlanmış olan bir işin parçası olmaktan zevk almamı sağladı" ifadesine verdiği görülmüştür.

Idari personelin verdiği en düşük puan $(3,75 \pm 0,97)$ "...sorunlara bakış açımı değiştirmemi sağladı" ifadesi için olurken, en yüksek puanı $(4,60 \pm 0,60)$ akademik personel ile benzer şekilde, "...başarıyla tamamlanmış olan bir işin parçası olmaktan zevk almamı sağladı" ifadesine verdiği belirlenmiştir. Personel statüsüne göre değerlendirildiğinde, katılımcılar tarafından ifadelere verilen puanların ortalamaları katılıyorum ve kesinlikle katılıyorum düzeyinde $(3,75 \leq$ Xort $\leq 4,73)$ olduğu görülmektedir.

Tablo 3 bir bütün olarak değerlendirildiğinde, takım çalışması etkinliklerine katıımın katıımcılar üzerinde büyük ölçüde olumlu etki yarattığı anlaşılmaktadır. 
Tablo 3. Katıımcıların Verdikleri Cevapların Kategorilere Göre Dağıımı

\begin{tabular}{lcccc}
\hline ifadeler & Cinsiyet & $\begin{array}{c}\text { Ortalama } \\
(\underline{X} \pm S D)\end{array}$ & $\begin{array}{c}\text { Personel } \\
\text { Statüsü }\end{array}$ & $\begin{array}{c}\text { Ortalama } \\
(\underline{X} \pm S D)\end{array}$ \\
\hline
\end{tabular}

Takım çalışması etkinliklerine katılmış olmak...

\begin{tabular}{|c|c|c|c|c|}
\hline \multirow{2}{*}{...eğitim seansları arasında enerjimi yenilememi sağladı. } & Erkek & $4,58 \pm 0,62$ & Akademik & $4,59 \pm 0,50$ \\
\hline & Kadın & $4,91 \pm 0,30$ & idari & $4,50 \pm 0,61$ \\
\hline \multirow{2}{*}{$\begin{array}{l}\text {...verilen eğitimin stresten uzak ve rahat bir ortamda } \\
\text { gerçekleştirilebilmesine katkı sağladı. }\end{array}$} & Erkek & $4,52 \pm 0,68$ & Akademik & $4,41 \pm 0,80$ \\
\hline & Kadın & $4,73 \pm 0,65$ & idari & $4,20 \pm 0,95$ \\
\hline \multirow[b]{2}{*}{...eğitim seanslarından yüksek verim almamı sağladı. } & Erkek & $4,52 \pm 0,51$ & Akademik & $4,59 \pm 0,73$ \\
\hline & Kadın & $4,64 \pm 0,67$ & idari & $4,40 \pm 0,60$ \\
\hline \multirow{2}{*}{$\begin{array}{l}\text {...başarıyla tamamlanmış olan bir işin parçası olmaktan } \\
\text { zevk almamı sağladı. }\end{array}$} & Erkek & $4,48 \pm 0,57$ & Akademik & $4,73 \pm 0,55$ \\
\hline & Kadın & $4,64 \pm 0,50$ & idari & $4,60 \pm 0,60$ \\
\hline \multirow{2}{*}{$\begin{array}{l}\text {...işlerin her zaman göründüğü gibi olmayabileceğini (kolay } \\
\text { görünenler zor, zor görünenler kolay olabilir) hissettirdi. }\end{array}$} & Erkek & $4,42 \pm 0,67$ & Akademik & $3,82 \pm 1,10$ \\
\hline & Kadın & $4,73 \pm 0,47$ & idari & $4,05 \pm 1,00$ \\
\hline \multirow{2}{*}{$\begin{array}{l}\text {...eğitim seanslarına düzenli katılım için motivasyonumu } \\
\text { arttırdı. }\end{array}$} & Erkek & $4,55 \pm 0,68$ & Akademik & $4,05 \pm 0,84$ \\
\hline & Kadın & $4,36 \pm 0,67$ & idari & $4,05 \pm 0,94$ \\
\hline \multirow{2}{*}{...kurumumdaki diğer çalışanları daha iyi tanımamı sağladı. } & Erkek & $4,39 \pm 0,72$ & Akademik & $4,64 \pm 0,58$ \\
\hline & Kadın & $4,73 \pm 0,47$ & idari & $4,30 \pm 0,73$ \\
\hline \multirow{2}{*}{$\begin{array}{l}\text {...gelecekte, bir takım çalışmasının parçası olmam } \\
\text { durumunda bana katkı sağlayacaktır. }\end{array}$} & Erkek & $4,45 \pm 0,62$ & Akademik & $4,64 \pm 0,73$ \\
\hline & Kadın & $4,45 \pm 0,52$ & idari & $4,50 \pm 0,61$ \\
\hline \multirow{2}{*}{...kurumsal aidiyet duygularımı olumlu yönde etkiledi. } & Erkek & $4,32 \pm 0,60$ & Akademik & $4,64 \pm 0,49$ \\
\hline & Kadın & $4,82 \pm 0,40$ & idari & $4,40 \pm 0,60$ \\
\hline \multirow{2}{*}{...empati kurma becerime katkı sağladı. } & Erkek & $4,23 \pm 0,92$ & Akademik & $4,50 \pm 0,60$ \\
\hline & Kadın & $4,55 \pm 0,69$ & idari & $4,40 \pm 0,60$ \\
\hline \multirow{2}{*}{$\begin{array}{l}\text {...diğerlerinin hatalarına karşı hoşgörülü olmama katkı } \\
\text { sağladı. }\end{array}$} & Erkek & $4,13 \pm 0,56$ & Akademik & $4,55 \pm 0,74$ \\
\hline & Kadın & $4,55 \pm 0,52$ & idari & $4,45 \pm 0,51$ \\
\hline \multirow{2}{*}{$\begin{array}{l}\text {...bir problemin çözümü için yeni yollar aramam } \\
\text { konusunda bakış açımı olumlu yönde etkiledi. }\end{array}$} & Erkek & $4,06 \pm 0,89$ & Akademik & $4,59 \pm 0,59$ \\
\hline & Kadın & $4,36 \pm 0,50$ & idari & $4,30 \pm 0,57$ \\
\hline \multirow{2}{*}{...iş yaşantıma olumlu katkı sağlayacaktır. } & Erkek & $4,06 \pm 0,81$ & Akademik & $4,32 \pm 0,48$ \\
\hline & Kadın & $4,00 \pm 0,89$ & idari & $4,15 \pm 0,67$ \\
\hline \multirow{2}{*}{...sorunlara bakış açımı değiştirmemi sağladı. } & Erkek & $4,03 \pm 0,87$ & Akademik & $4,18 \pm 0,59$ \\
\hline & Kadın & $4,09 \pm 0,94$ & idari & $3,75 \pm 0,97$ \\
\hline \multirow{2}{*}{...sınırlarımın ne olduğu fark etmemi sağladı. } & Erkek & $3,97 \pm 0,75$ & Akademik & $4,41 \pm 0,73$ \\
\hline & Kadın & $4,00 \pm 1,00$ & idari & $3,85 \pm 0,81$ \\
\hline \multirow[b]{2}{*}{...problem çözme becerime katkı sağladı. } & Erkek & $3,87 \pm 1,06$ & Akademik & $4,14 \pm 0,83$ \\
\hline & Kadın & $4,09 \pm 1,04$ & idari & $3,95 \pm 0,83$ \\
\hline
\end{tabular}

Elde edilen verilerde, cinsiyetlere göre istatististiksel olarak anlamlı fark olup olmadığının incelenmesi amacıyla MWU testi yapılmış ve "...kurumsal aidiyet duygularımı olumlu yönde etkiledi." ifadesine verilen cevaplarda kadınlar ile erkeklerin sıra ortalamaları arasında (kadın=28,6; erkek=19,06) istatistiksel olarak anlamlı bir fark olduğu ( $U=95,00 ; p=0,03)$ (Tablo 4) görülmüştür. Diğer ifadelerin hiçbirinde anlamlı farka rastlanmamıştır ( $p>0,05)$. 
Tablo 4. Etkinliklere Katıııın Cinsiyet Değişkenine Göre İncelenmesi

\begin{tabular}{|c|c|c|}
\hline $\begin{array}{l}\text { Etkinlikler kurumsal aidiyet duygularımı olumlu yönde } \\
\text { etkiledi. }\end{array}$ & Erkek $(n=31)$ & Kadın $(n=11)$ \\
\hline Sıra Ortalaması & 19,06 & 28,36 \\
\hline Sıralar Toplamı & 591,00 & 312,00 \\
\hline Mann-Whitney U & & \\
\hline$Z$ & & \\
\hline$p$ & & \\
\hline
\end{tabular}

${ }^{*} \mathrm{p}<0,05$

Katılımcıların verdikleri cevaplarda kadro değişkenine (akademik, idari) göre istatistiksel olarak anlamlı bir fark olup olmadığının MWU testi ile incelenmesi sonucunda, akademik personel ile idari personel arasında yalnızca "...bir problemin çözümü için yeni yollar aramam konusunda bakış açımı değiştirdi." ifadesinde (Tablo 5) anlamlı fark olduğu $(U=130 ; p<0,05)$, diğer ifadelerde fark olmadığı görülmüştür. Akademik personelin bu ifadedeki sıra ortalaması 25,57 iken idari personelin sıra ortalaması 28,36'dır.

Tablo 5. Etkinliklere Katılımın Cinsiyet Değişkenine Göre İncelenmesi

\begin{tabular}{|c|c|c|c|}
\hline \multicolumn{2}{|c|}{$\begin{array}{l}\text { Etkinlikler bir problemin çözümü için yeni yollar arama } \\
\text { konusunda bakış } \\
\text { açımı olumlu yönde değiştirdi. }\end{array}$} & Erkek $(n=31)$ & Kadın $(n=11)$ \\
\hline & Sira Ortalaması & 25.57 & 28,36 \\
\hline & Sıralar Toplamı & 562,5 & 340,50 \\
\hline & Mann-Whitney U & \multicolumn{2}{|c|}{130,00} \\
\hline & $z$ & \multicolumn{2}{|c|}{$-2,522$} \\
\hline & $p$ & \multicolumn{2}{|c|}{$0,012^{*}$} \\
\hline
\end{tabular}

${ }^{*} p<0,05$

Daha önce takım çalışması etkinliklerine katıım sağlamış olma durumu (katıldım, katılmadım) hiçbir ifadede anlamlı farka neden olmamıştır $(p>0,05)$. Çoklu gruplar arasındaki karşılaştırmaların yapılabilmesi için KW testi uygulanmış ve gruplar arasında istatistiksel olarak anlamlı fark olup olmadığı incelenmiştir. Test sonuçlarına göre, kurumda çalışma süresi değişkeninde, "...eğitim seanslarına düzenli katılım için motivasyonumu arttırdı." ve "...verilen eğitimin stresten uzak ve rahat bir ortamda gerçekleştirilebilmesine katkı sağladı." ifadelerine verilen cevaplarda gruplar arasında fark olduğu $(p<0,05)$, diğer ifadelere verilen cevaplarda gruplar arasında istatistiksel olarak anlamlı bir fark bulunmadığı $(p>0,05)$ görülmüştür. Kurumda çalışma süresine göre ifadelerin hangi gruplar arasında farklıık gösterdiğinin incelenmesi için MWU testi kullanılarak ikili karşılaştırmalar yapılmıştır. Bonferroni düzeltmesi yapılarak hesaplanmış olan $\mathrm{p}<0,0125$ değeri, anlamlılık düzeyi olarak kabul edilmiştir. Buna göre, Tablo 6'da verildiği üzere, yalnızca 0-4 yıl ile 15-19 yıl kategorileri arasında anlamlı bir fark bulunduğu görülmüştür $(p<0,0125)$.

Tablo 5. Etkinliklere Katıımın Kurumda Çalışma Süresi Değişkenine Göre İncelenmesi

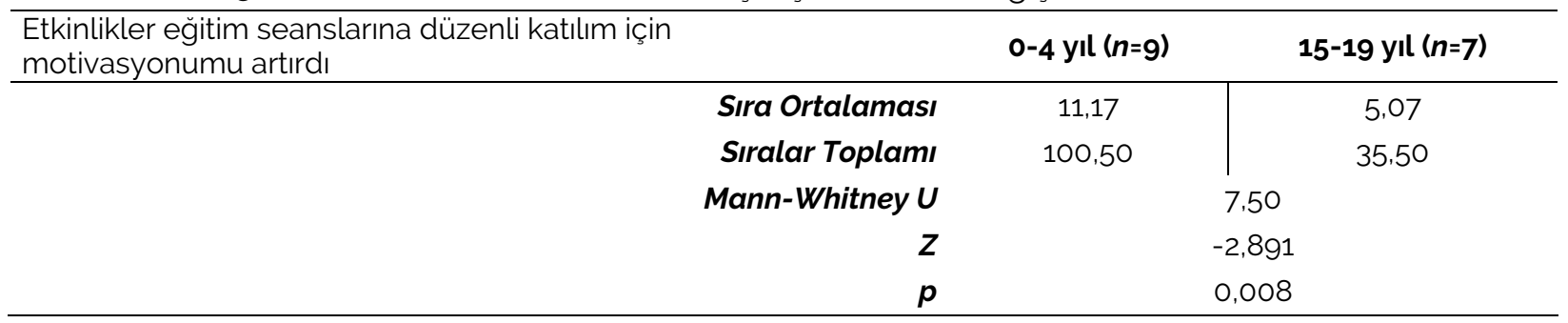




\section{Tartışma ve Sonuç}

Yapılan çalışmadan elde edilen veriler ışığında, takım çalışması etkinliklerine katııma ilişkin değerlendirme ifadelerine verilen puanların, incelenen kategorilerde (cinsiyet ve personel statüsü) yüksek ile çok yüksek düzeylerinde olduğu ve takım çalışmalarına katılmış olmanın personel üzerinde pozitif etkiye sahip olduğu, cinsiyet ya da statü kategorilerine göre, elde edilen puanlarda istatistiksel olarak anlamlı farkların olmadığı ortaya konmuştur. Polatcı ve diğerleri (2008) tarafından yapılan ve akademik kurumlarda örgüt sağlığı ve örgüt sağlığını etkileyen değişkenlerin incelendiği çalışmanın sonucunda, akademik personelin örgüt sağlığı ile ilgili algılarının cinsiyet, akademik unvan ve mesleki kıdeme göre farklılık göstermediği bulunmuştur.

Puanlar arasındaki farkların değerlendirilmesi için yapılan istatistiksel inceleme sonuçlarının da desteklediği üzere, cinsiyet ve personel statüsü kategorilerine göre yapılan incelemelerde her kategori için yalnızca birer ifadede fark olmakla birlikte, diğer tüm maddelere verilen puanlar homojen bir yapıda ve yüksektir. Elde edilen puanlar, katıımcıların takım çalışması etkinlikleri ile zenginleştirilmiş eğitim çalışmalarından duydukları memnuniyetin ve takım çalışması etkinliklerinin faydalı olduğunun bir göstergesi olarak kabul edilebilir. Kategorilere göre ifadelerden elde edilen puanlar arasında istatistiksel olarak anlamlı fark bulunamamış olması da bu görüşü desteklemektedir. Buna göre, yapılan kurumsal eğitim programlarının içerisine adapte edilmiş olan takım çalışması faaliyetlerinin, katıımcıların kurumsal aidiyet duygusu, çalışma motivasyonu ve iş verimi başta olmak üzere pek çok açıdan fayda sağlayacağı söylenebilir.

Çalışma yaşamının kalitesine etki eden birçok faktör bulunmaktadır. Can'a (1991) göre çalışma hayatının kalitesi; çalışmayı doğrudan ya da dolaylı etkileyen; iş (yapısı, organizasyonu), ücretler, kazançlar, çalışma ortamı ve şartları, işlerin yönetim ve organizasyonu, işte kullanılan teknoloji, çalışan (personel, işçi) tatmini ve motivasyonu, endüstriyel ilişkiler, katıım, istihdam güvencesi, sosyal adalet ve sosyal güvenlik, demografik yapı ve sürekli eğitim gibi faktörler birer belirleyicidir. Çalışma yaşamı kalitesini etkileyen farklı sınıflamalar da bulunmaktadır.

Genel olarak çalışma yaşamı kalitesi; iş yerinin kendisine, dizaynına, ergonomik yapısına, işgörenin motivasyon derecesine, işten aldığı tatmine, işletmede çağdaş yönetim ilkelerinin uygulanmasına ve teknolojik yeniliklerin kullanılmasına bağlı olarak artırılabilir (Erdem ve Kaya, 2013). Kendi kurumlarına karşı olumlu tutum geliştirmiş olan çalışanların çalışma verimlerinin arttığı ve bu durumun kurum lehine sonuçlar doğurduğu, yapılan çalışmalar sonucunda ortaya konmuştur (Baran ve Çelik, 2017). Bireylerin davranışları yalnızca dışsal kaynaklar (ödül ya da ceza gibi) tarafından değil, yapılan içsel değerlendirmelerin sonucuna göre de şekillenmektedir. Kurum çalışanları kendi performans standartlarını, öznel değerlendirmelerini ve davranışlarının ne şekilde olacağını, kurum atmosferine bağlı olarak yapmaktadırlar (Cohen, Chang ve Ledford, 1997). Buna göre, kurum atmosferinin iyi olması, çalışanlar arasındaki uyum ve kurumsal aidiyet duygusu, bireylerin motivasyonunu artırmakta ve verimliliği yükseltmektedir. Çalışanlara kalite için verilen eğitimlerin sonunda elde edilen verilere bakıldığında (Tablo 3) katılımcıların genel olarak memnun oldukları (ölçekteki ifadelerden elde edilen en düşük ortalama 3,75ะ0,97'dir) görülmektedir.

Eğitim faaliyeti sırasında, takım çalışmasına yönelik etkinlikere katılanların \%35.71'i bu etkinliklerin faydalı olduğunu ifade ederken, \%64,29'u çok faydalı olduğunu ifade etmişlerdir. Özellikle yönetici pozisyonundaki çalışanların takım çalışması etkinliklerini olumlu algılamalarının, hem kurumun işleyiş̧ini ve dolaylı olarak da hiyerarşik ilişkileri yönetmede hem de çalışılabilir bir iş ortamının yaratıımasında katkı sağlayacağı düşünülmektedir. 
Hertting ve diğerleri (2003), 1997-2000 yılları arasında İsveç sağlık bakımı sisteminde meydana gelen yapısal değişikliklerin tıbbi sekreterler üzerinde oluşturduğu stres ve motivasyon faktörlerini inceledikleri çalışmalarında, çalışanlar tarafından algılanan stres kaynağı olarak aşırı iş yükü ve tanınma eksikliğinin çalışma motivasyonunu olumsuz etkilediğini vurgulamışlardır.

Mevcut çalışmada, takım çalışmalarına katılım sağlayan yöneticilerin, motivasyonlarının arttığını, kurumlarındaki diğer çalışanları daha iyi tanıdıklarını, enerjilerini yenildiklerini, stresten uzak ve bir ortamda eğitim aldıklarını, eğitim seanslarına düzenli katııım sağladıklarını ve eğitim seanslarından yüksek verim aldıklarını ifade etmiş olmalarının iş yaşantılarında stres kaynaklarından uzaklaşma açısından oldukça önemli etki yaratacağı söylenebilir. Çalışanların birbirleri tarafından daha iyi tanınmasını sağlamasına katkı sağlamış olması açısından değerlendirildiğinde, yürütülmüş olan takım çalışması etkinliklerinin çalışma ortamında potansiyel olarak görülebilecek ve birbirini iyi tanımamaya bağlı olarak ortaya çıkabilecek olan önemli bir stres kaynağının ortadan kaldırımasında fayda sağlayabileceği sonucuna varılabilir.

Insan kaynakları yönetiminde başarı için; çalışanların kişisel özelliklerinin, beklentilerinin, işletmeye sundukları katma değerin doğru olarak tespit edilmesi ve yönetilmesi kadar, çalışanların bir araya gelerek oluşturdukları gruplar ve bu gruplar arasındaki etkileşimin ne olduğu da oldukça önemlidir (Dereli \& Cengiz, 2011).

Yöneticiler grup dinamiklerini ve ölçüm sonuçlarını değerlendirdiklerinde, kendi örgütleri içerisinde yapılacak çalışmalarda ya da proje gruplarında kimlerin uyum içinde çalışabileceğini, kimlerin grubu ne yönde etkileyebileceğini saptayabilirler (Dereli \& Cengiz, 2011). Bu da, yöneticilerin çalışma ortamının huzurlu ve ortaya çıkan ürünlerin kaliteli olmasını sağlamaları yönünde yardımcı olacaktır. Ayrıca, çalışma kalitesinin genel amaçlarından birinin, çalışanların verimlilik düzeylerinin arttırıması ve iş kayıplarının azaltılması olduğu belirtilmektedir (Dikmetaş, 2006). Bunlara ilave olarak; kurumsal aidiyet, yeterli iletişim, çalışan memnuniyeti ve sorun çözme yeterliliği gibi kavramların örgüt sağlığını oluşturan boyutlardan bazıları olduğu bilinmektedir (Polatcı, Ardıç \& Kaya, 2008).

Çalışmadan elde edilmiş olan veriler değerlendirildiğinde, etkinliklere katılım sağlayan yöneticilerin kurumsal aidiyet duygularının ve empati becerilerinin olumlu etkilendiği, takımın bir parçası olmaktan haz aldıkları ve gelecekte de bir işin parçası olmaya istekli oldukları görülmüştür. Buna göre, takım çalışmalarına katıım sağlayan yöneticilerin, kurum içerisinde gerçekleştirilecek olan grup ya da proje çalışmalarında daha yüksek verimle görev alabilecekleri ve personelin de bundan olumlu olarak etkilenebileceği, oluşan sinerji sayesinde de toplam verim artışına katkı sağlanabileceği değerlendirilmektedir.

Personele verilen eğitimlerde, personele eğitim alanında isteklilik sağlanması önerilmektedir. Eğitime katıım için istekli olmak, katıımcıların eğitimde verilen bilgileri öğrenmesini kolaylaştırmakta ve güdülenmenin hızlı bir şekilde gerçekleşmesini sağlamaktadır (Selimoğlu ve Yılmaz, 200g). Elde edilen veriler değerlendirildiğinde, eğitim seansları arasında takım çalışmalarına katıım sağlamış olmanın, enerjinin yenilenmesinde çok büyük etkisinin olduğu ve eğitim seanslarından yüksek verim almayı sağladığı görülmüştür. Buna göre, takım çalışması etkinliklerinin, eğitim faaliyetinden elde edilmesi beklenen öğrenme düzeyini olumlu şekilde etkilemiş olabileceği öngörülmektedir.

Gruplar ve çalışanlar arasında koordinasyonu sağlamak, etkin bir iletişim ortamı yaratmak, işten duyulan tatmini ve motivasyonu arttırmak, işletmelere rekabet üstünlüğü kazandırarak pek çok olumlu katkı sağlar. İşletme içinde çatışmaların ortaya çıkması hatta düşmanlığın oluşması, verimliliğin düşmesi, rekabet gücünde azalma gibi olumsuz sonuçlar da ortaya çıkabilmektedir. Bu olumsuz sonuçların ortaya çıkmasının ortadan kaldırılabilmesi ya da en aza indirgenebilmesi için yönetici 
pozisyonundaki kişilerin grupların işleyişi, grup üyelerinin ayırt edici özellikleri, birbirleriyle uyumları ve grup dinamikleri ile ilgili farkındalıklarının yüksek olması gerekmektedir. Belirtilen konularla ilgili yapılan gözlemlerde uygun yöntem ve tekniklerin kullanılması da gerekmektedir ve bu husus işletmeler için oldukça önemli olmakla birlikte (Dereli ve Cengiz, 2011) üniversite çalışanları açısından da en az işletmelerde olduğu kadar önemlidir.

Sonuç olarak, takım çalışması etkinliklerine katılımın üniversite yöneticilerinin profesyonel faaliyetlerine olumlu katkı sağladığı, katıımcıların motivasyonlarının yükseltilmesine katkı sağlaması nedeniyle yapılan eğitim faaliyetlerinden elde edilen verimin artmasına sebep olduğu, eğitim sürecini ve kazanımlarını pozitif yönde desteklediği bulunmuştur. Buna göre, kurumsal eğitim ve değerlendirme toplantıları gibi faaliyetlerin takım çalışması etkinlikleri ile zenginleştirilmesinin katılımcılar açısından olduğu kadar, katıımcıların kurum yöneticisi olması nedeniyle, kurum açısından da faydalı olacağı değerlendirilmektedir. Kurum içi eğitim faaliyetlerinden beklenen verim düzeyine ulaşılmasına katkı sağlaması açısından, eğitim planı içerisine takım çalışması etkinliklerinin de dâhil edilmesi önerilmektedir.

\section{Kaynakça}

Aktan, C. C. \& Yay, S. (2016). Organizasyonel değişimde iki farklı kültür: değişim kültürü ve değiş̧ime direnç kültürü. Organizasyon ve Yönetim Bilimleri Dergisi. 8(2), 1-16.

Baran, M. \& Çelik, Y. (2017). The relationship between employee perceptions of corporate social responsibility and job satisfaction. Journal of Behavior at Work. 2(1), 63-79.

Bek, N. (2008). Fiziksel Aktivite ve Sağlığımız. Ankara, Klasmat Matbaacılık. s. 7-18.

Can, A. (1991). I. Verimlilik kongresi "Çalışma hayatının kalitesinin geliştirilmesi". Ankara. MPM Yayınları. S. 89-99.

Cohen, S. S., Chang, L. \& Ledford, G. E. (1997). A hierarchical construct of self-management leadership and its relationship to quality of work life and perceived work group effectiveness. Personnel Psychology. 50, 275-308.

Dereli, B. \& Cengiz, D. (2011). Innsan kaynakları yönetiminde grup dinamiği kavramları ve grup dinamiğinin ölçülmesi üzerine uygulama örneği. Öneri. 9(35), 35-43.

Dikmetaş, E. (2006). Hastane personelinin çalışma/iş yaşam kalitesine yönelik bir araştırma. Ç.Ü. Sosyal Bilimler Enstitüsü Dergisi. 15(2), 169-182.

Erdem, B. \& Kaya, i. (2013). Çalışma yaşamı kalitesini etkileyen faktörlerin işgörenler tarafından algılanması: otel çalışanları üzerinde bir araştırma. Dumlupınar Üniversitesi Sosyal Bilimler Dergisi. 35, 135-150.

Görmüş, A. \& Kahya, V. (2014). The effect of in-service training programmes on public employees' motivation: an application in ETI mine enterprises. Optimum Ekonomi ve Yönetim Bilimleri Dergisi. 1(1), 37-49.

Güçlü, N. \& Okçu V. (2015). Ilköğretim öğretmenlerinin etkili takım çalışmasına ilişkin algıları ile örgütsel bağlılıkları arasındaki ilişki. YYU Journal of Education Faculty. 12(1), 49-6.

Gürbüz, M. \& Aydın, A. H. (2012). Zaman kavramı ve yönetimi. KSÜ Sosyal Bilimler Dergisi. 9(2), 1-20.

Hertting, A., Nilsson, K., Theorell, T. \& Larsson U. (2003). Personnel reductions and structural changes in healthcare work-life experiences of medical secretaries. Journal of Psychosomatic Research. 54, 161-170. 
İlhan, A. \& Ince, E. (2015). Takım çalışması ve takım etkinliğini belirleyen faktörlerin ölçülmesi: gaziantep üniversitesinde bir uygulama. Kahramanmaraş Sütçü Imam Üniversitesi İtisadi ve Idari Bilimler Fakültesi Dergisi. 5(1), 127-152.

Polatcı, S., Ardıç, K. \& Kaya, A. (2008). Akademik kurumlarda örgüt sağlığı ve örgüt sağlığını etkileyen değişkenlerin analizi. Yönetim ve Ekonomi. 15(2), 145-161.

Selimoğlu, E. \& Yılmaz, H. B. (2009). Hizmet içi eğitimin kurum ve çalışanlar üzerine etkileri. Paradoks Ekonomi, Sosyoloji ve Politika Dergisi. 5(1), 1-12.

Yetim, A. (2000). Sporun sosyal görünümü. Gazi Beden Eğitimi ve Spor Bilimleri Dergisi. 1(5), 61-70. 